\title{
Sequential Design of Experiments for Removal of Methylene Blue Dye by Electrocoagulation Associated with Dissolved-Air System
}

\author{
Mauro C. C. Góes, ${ }^{a}$ Marcos P. R. Garcez, ${ }^{a}$ Claudemir G. Santana, ${ }^{a}$ \\ Jonas J. G. Costa Neto ${ }^{b}$ and Cicero W. B. Bezerra ${ }^{\circledR} * a$ \\ ${ }^{a}$ Laboratório de Química de Interfaces e Materiais, Departamento de Química, \\ Universidade Federal do Maranhão, Av. dos Portugueses, 1966, \\ Campus do Bacanga, 65080-805 São Luís-MA, Brazil \\ ${ }^{b}$ Laboratório de Tecnologia de Processos Químicos e Bioquímicos, Instituto Federal do Maranhão, \\ Av. dos Curiós, s/n, Campus do Maracanã, 65095-460 São Luís-MA, Brazil
}

\begin{abstract}
The present work presents a strategic sequential experimental planning to evaluate the removal of methylene blue dye from aqueous medium by electrocoagulation combined with dissolved air flotation. Effect of electrode pairs, electrode spacing, contact time, initial $\mathrm{pH}$, voltage, and pressure were optimized according to the following response variables: color, final $\mathrm{pH}$, turbidity, and dye removal. The best-achieved optimized conditions were: 4 pairs of electrodes, $2.5 \mathrm{~cm}$ spacing, electrolysis time of $203 \mathrm{~min}$, initial $\mathrm{pH}$ 4, voltage of $32 \mathrm{~V}$, and no pressure by dissolved air injection. Among the experimental results, it was possible to obtain a maximum removal of $95.1 \%$ of the dye. The analysis of the response surfaces showed that the initial $\mathrm{pH}$ has a great influence on the final characteristic of the treated effluent. Through the study of optimization, synthetic effluents have been obtained that meet the discharge standards according to the current Brazilian environmental legislation.
\end{abstract}

Keywords: electrocoagulation, DAF, CCRD, methylene blue

\section{Introduction}

The growth of industrial activities and urban centers has been increasing the concentration of pollutants in water bodies. Dyes are a relevant example, as they are widely employed in various industries such as textiles, paper and cellulose, plastics, pharmaceutical products, food products, and others. In addition, they are highly toxic and able to cause major environmental damage. These compounds when discarded into aquatic bodies reduce the absorption of light and cause negative impacts to photosynthesis. Furthermore, due to their complex structures, they have low degradability, they are cancerous and thermoresistant. Thus, the occurrence of these dyes in effluents, even at low concentrations, can be harmful to human health and to the environment. ${ }^{1,2}$

Textile industries are well-known for consuming a high volume of water and for producing an equivalent amount of wastewater. In fact, it is estimated that around 300 thousand tons of textile wastewater are discharged

*e-mail: cwbbezerra@hotmail.com yearly wordwide. ${ }^{3}$ Such effluents are of complex composition, usually containing a mixture of salts, acids, heavy metals, dispersants, surfactants, suspended and dissolved solids, organ-chlorine-based pesticides, pigments and dyes. ${ }^{3,4}$

Considering these facts, efforts have been made to establish treatment methodologies for the textile wastewater, with the adoption of fast, efficient and lowcost techniques. Ubale and Salkar ${ }^{5}$ comment that advanced oxidation processes, like photo-oxidation by $\mathrm{UV} / \mathrm{H}_{2} \mathrm{O}_{2}$ or $\mathrm{UV} / \mathrm{TiO}_{2}$, may require complementary chemicals and cause a secondary pollution. They also point out that biological methods, although cheaper than other methods, can become inefficient due to the dyes' toxicity, which inhibits bacterial development. Aerobic treatment may also not be applied to full-scale textile wastewater treatments because it is usually a very slow process, requires nutrient control and nitrogenconstrained environments, and also can promote the growth of autochthonous microorganisms. ${ }^{6}$ Currently, among chemical methods, electrocoagulation (EC) treatment is one of the most advanced processes, and it can offer good removal efficiencies using compact reactors and simple 
equipment, still being a simple, efficient and eco-friendly process. $^{5}$

Electrocoagulation (EC) has also been applied to urban wastewater and others industrial waste. ${ }^{7,8}$ This technique is ecological, easy to operate and automate, has a short retention time, low costs, low production of sludge, and usually does not require the addition of flocculation agents. It is based on in situ generation of the coagulant agent by electrolytic oxidation of sacrificial anodes, followed by pollutant destabilization, formation of suspended particles and consequent agglomeration of such resultant particles to generate flocs. ${ }^{9}$

The main reactions that usually occur at electrodes may be expressed as: ${ }^{10,11}$

Anode: $\mathrm{M}_{(\mathrm{s})} \rightarrow \mathrm{M}_{(\mathrm{aq})}^{\mathrm{x}+}+\mathrm{x} \mathrm{e}^{-}$

Cathode: $2 \mathrm{H}_{2} \mathrm{O}_{(\mathrm{l})}+2 \mathrm{e}^{-} \rightarrow 2 \mathrm{OH}_{(\mathrm{aq})}^{-}+\mathrm{H}_{2(\mathrm{~g})}$

In the anode, according to $\mathrm{pH}$, there is still the possibility of the release of oxygen gas:

Anode: $4 \mathrm{OH}_{(\mathrm{aq})}^{-} \rightarrow 2 \mathrm{H}_{2} \mathrm{O}_{(\mathrm{l})}+\mathrm{O}_{2(\mathrm{~g})}+4 \mathrm{e}^{-}$

EC has been the subject of study by several researchers. ${ }^{12-17}$ At the same time that the coagulant agent is generated in situ, the water electrolysis produces gas bubbles with small diameters $(15-80 \mu \mathrm{m})^{12}$ and considerable surface area, promoting an efficient removal of fine particles. $^{13}$

The performance of the EC unit is strictly related to the definition of the operating conditions that best apply to the treatment demand. For instance, the nature of the electrodes is important since the produced cations must favor the interaction with the pollutants, allowing the effective removal of the formed particles. ${ }^{17}$ The efficiency of an EC unit depends on factors such: reduction of the voltage drop between electrodes, reduction of the gas accumulation on the electrode surfaces, and low resistance to mass transfer in the interelectrode region. ${ }^{10}$ The geometrical configuration of the reactor, the electrode layout, and the electrical conductivity contribute to the voltage drop between electrodes. In addition, the bubbles production causes an insulating layer on the electrode surface, which increases the internal resistance of the EC cell reducing the mobility of the species in solution, thus acting directly on the separation of the flocculated particles in the flotation stage. ${ }^{10}$ In order to define cell configurations for better treatment performance, the literature has presented some innovations, such: wireless electrocoagulation ${ }^{18}$ and associated application with ceramic membrane microfiltration, ${ }^{19}$ sand filtration, ${ }^{20}$ and dissolved air flotation (DAF).$^{10-12}$
DAF method also makes use of microbubbles (20-100 $\mu \mathrm{m})$ through compressed air dissolved in the effluent under high pressure. This technology uses simple, compact, and practical (easily operable and adaptable) equipment, ${ }^{12,21}$ and has already been used in the seawater desalination pre-treatment, ${ }^{21}$ as well as in the separation of plastic waste from aqueous medium. ${ }^{22}$

The application of EC and DAF processes in wastewater treatment aims to remove as many pollutants as possible. Therefore, it is necessary to establish optimal conditions for the effective application of these techniques. Many studies concerning water treatment by EC were performed using univariate optimization strategy, which is efficient only if there is no interaction between variables. In these cases, where the factors are studied one at a time while keeping the other variables constant, there is no guarantee for the establishment of the best separation conditions. Furthermore, this experimental scheme tends to be tedious and timeconsuming. ${ }^{23-29}$ Besides, there is a recognized absence of systematic research on EC-DAF, as well as a lack of systematic approaches to the optimization of electrochemical reactors. ${ }^{28}$ The establishment of the best experimental configuration, adjusting the process parameters to achieve optimum performance, will not only reduce operational costs but also enhance the process yield, advantages that can solve environmental problems in a short time.

A few studies ${ }^{29-32}$ report the use of the response surface methodology (RSM) applied to the degradation of dyes from effluents by EC. Assémian et al. ${ }^{29}$ treated textile bio-refractory wastewater by EC using an electrolytic cell equipped with iron electrodes, in a parallel monopolar configuration. Applying experimental factorial design, they observed that the electrolysis time and current intensity were the main influential parameters in the treatment, with a cumulative contribution of more than $94 \%$ for each of the three studied responses: turbidity, chemical oxygen demand (COD) and absorbance, whereas $\mathrm{pH}$ interactions were almost negligible. Further experimental design (central composite design) allowed them to establish these optimal treatment conditions: $4500 \mathrm{~s} ; 2.61 \mathrm{~A}$ and $\mathrm{pH}=6.83$, which predicted reduction of $99.95 \%$ in turbidity; $78.87 \%$ in COD, and $84.91 \%$ in absorbance.

Amani-Ghadim et al..$^{30}$ by EC, and through the response surface methodology (RSM), optimized and modeled the removal of the reactive Red Dye 43. The experiments were conducted in a monopolar batch reactor, using two anodes ( $\mathrm{Fe}$ and $\mathrm{Al}$ ) and two cathodes in parallel connections. Current density, time, $\mathrm{pH}$, and chloride concentration were considered independent variables. Using RSM and under ideal conditions, the dye removal efficiency was greater than $99 \%$ for both electrodes. 
Mondal et al. ${ }^{31}$ treat a textile printing dye-bath effluent by EC using aluminum electrode in a batch mode and various operating parameters (initial $\mathrm{pH}$, current density, electrolysis time, and inter-electrode distance). Multiresponse optimization with a desirability function approach was used to simultaneously maximize COD (94\%) and color removal $(99.7 \%)$, and minimize specific energy consumed $\left(0.011 \mathrm{~kW} \mathrm{~h} \mathrm{~kg}^{-1}\right.$ of COD removed).

Taheri et $a l .{ }^{32}$ applied RSM and adaptive neuro fuzzy inference system (ANFIS) models for optimization of reactive Blue 19 removal through combined electrocoagulation/coagulation process. The effects of five independent parameters (current, reaction time, initial dye concentration, initial $\mathrm{pH}$, and dosage of poly aluminum chloride) were studied. According to the RSM results, all the independent parameters are equally important in dye removal efficiency. In this study, $99.67 \%$ of dye removal efficiency was obtained.

As it can be noticed, due to the diversity of experimental configurations, it is difficult to perform an accurate and conclusive analysis of the optimal conditions for effluent treatment. In addition, statistical modelling has not yet been explored for feasibility studies of the combined action of DAF technology with the EC technique, with the simultaneous effects of the variables on an electrochemical system. In consequence, there is a need for a broader study regarding the variables and working ranges, in order to establish which factors are significant and thus could be used at a treatment scale.

Therefore, the aim of this study was to evaluate the efficiency of the use of EC-DAF for the treatment of synthetic textile dye wastewater, establishing the best experimental conditions through experimental planning. To the best of our knowledge, the present work shows for the first time, and for these combined techniques, an exhaustive statistical treatment (fractional factorial design (FFD) $2^{\mathrm{k}-\mathrm{p}}$; followed by a central composite rotational design (CCRD)) involving not only a significant number of important operational variables (electrode pairs (EP); electrode space (ES); electrolysis time $(\mathrm{t})$; initial $\mathrm{pH}$ $\left(\mathrm{pH}_{\mathrm{i}}\right)$; potential difference $(\mathrm{PD})$; and dissolved air pressure (P)) but also a wide variation range for each considered variable.

\section{Experimental}

\section{Reagents, solutions and equipment}

All chemicals used were of analytical grade: methylene blue (MB), $\mathrm{C}_{16} \mathrm{H}_{18} \mathrm{ClN}_{3} \mathrm{~S}$, potassium chloride, $\mathrm{KCl}$ and, sodium hydroxide, $\mathrm{NaOH}$ (Isofar, Duque de Caxias, Rio de Janeiro, Brazil); hydrochloric acid, $\mathrm{HCl}$ (Emsure ${ }^{\circledR}$, Merck-Millipore, São Paulo, Brazil); standard color solution APHA platinum-cobalt (Quimlab, Jacareí, São Paulo, Brazil). Aluminum electrodes were made from a $0.001 \mathrm{~m}$ thick blade with an active electrode surface of $4.14 \times 10^{-3} \mathrm{~m}^{2}$. All the solutions were prepared with distilled water. Table 1 shows the initial characteristics of the prepared MB solutions.

The $\mathrm{pH}$ was adjusted with diluted $\mathrm{HCl}$ and $\mathrm{NaOH}$ solutions. A pH meter with combined glass electrode and temperature correction was used (model Q400AS, Quimis, São Paulo, Brazil). A turbidimeter (model TB-1000, MS Tecnopon, São Paulo, Brazil) was used to determine the turbidity of all treated effluent at the end of each experiment, according to the Standard Methods for the Examination of Water and Wastewater. ${ }^{33}$ Visible spectra of the solutions were recorded on a Kasuaki UV-Vis spectrophotometer (Tokyo, Japan), model IL-592S-BI. Absorbance measurements were carried out in order to determine $\mathrm{MB}$ concentration $(665 \mathrm{~nm})$ and to perform residual color analysis $(440 \mathrm{~nm})$. For both determinations, analytical curves were obtained under the following conditions: MB (MB: $1.6 \times 10^{-3}-1.6 \times 10^{-2} \mathrm{mmol} \mathrm{L}^{-1}$; $10 \mathrm{mmol} \mathrm{L}^{-1} \mathrm{KCl}$; pH's from 2.0 to 9.0); color (APHA standards; 25-500 uH). A Hikari DC adjustable power source, model HF-3203S (São Paulo, Brazil), was used as energy source to connect the aluminum electrodes in parallel.

\section{Experimental setup}

Figure 1 shows a schematic diagram of the experimental setup. The electrocoagulation cell was made of acrylic glass and designed with the following internal dimensions: $0.3 \times 0.15 \times 0.25 \mathrm{~m}$. For fitting and controlling the electrodes spacing, the cell cover was made contained

Table 1. Characteristics of methylene blue (MB) solutions

\begin{tabular}{lccccccccc}
\hline Solution & 1 & 2 & 3 & 4 & 5 & 6 & 7 & 8 & 9 \\
\hline Color / uH & 302 & 270 & 289 & 245 & 230 & 219 & 212 & 232 & 207 \\
$\mathrm{pH}_{\mathrm{i}}$ & 2.00 & 3.00 & 4.00 & 5.00 & 5.50 & 6.00 & 7.00 & 8.00 & 9.00 \\
Turbidity / NTU & 0.90 & 0.43 & 0.32 & 0.15 & 2.50 & 0.56 & 0.35 & 0.85 & -0.10 \\
\hline
\end{tabular}

uH: hazen unit; NTU: nephelometric turbidity unit. 
22 slits with $0.01 \mathrm{~m}$ spacing between them. A small cylindrical device $(0.01 \mathrm{~m}$ in diameter) containing small holes to provide a better distribution of dissolved air was installed at the bottom of the cell, functioning as a diffuser in the expansion chamber.

A DAF chamber was made of stainless steel $(0.005 \mathrm{~m}$ thick), with the following external dimensions: $0.16 \mathrm{~m}$ in diameter of the base and $0.25 \mathrm{~m}$ in height. In the upper part of the cylinder, a pressure gauge and two valves were installed: one for the water inlet and the other for the air inlet coming from a mega air CFA 7.6/24L compressor (Ferrari, Cotia, São Paulo, Brazil). For a better water supersaturation, the air inlet was internally extended to the bottom of the cylinder. In addition, and to check the water level inside the cylinder, a viewfinder was added on the upper side of the chamber.

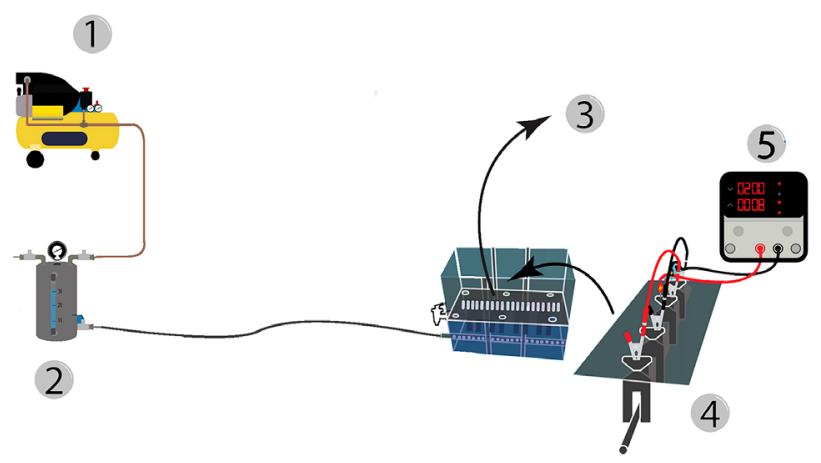

Figure 1. Detail of EC-DAF reactor and experimental setup: (1) compressor pump; (2) saturation vessel; (3) electrocoagulation cell; (4) electrodes; (5) power supply.

\section{Electrocoagulation tests}

For each experiment, $4.0 \mathrm{~L}$ of the synthetic effluent (MB $1.6 \times 10^{-2} \mathrm{mmol} \mathrm{L}^{-1} ; 10 \mathrm{mmol} \mathrm{L}-1 \mathrm{KCl}$ ) were put in the reactor (electrocoagulation cell), at $298 \mathrm{~K}$ and under adjusted $\mathrm{pH}$ conditions. All aluminum electrodes were cleaned, dried and weighed before and after each run. In the DF chamber, $3 \mathrm{~L}$ of distilled water dissolved the compressed air at the pressure established by the experimental design. After the electrochemical step, in which aluminum ions were released at the anode, enabling the coagulation process, $2 \mathrm{~L}$ of supersaturated solution of air in water were released from the DAF chamber. After $900 \mathrm{~s}$, a volume of the residual effluent was collected through an outlet installed at the bottom of the cell, and filtered (filter paper) for further color, $\mathrm{pH}_{\mathrm{f}}$ (final $\mathrm{pH}$ ), turbidity and $\mathrm{MB}$ concentration analysis.

The removal efficiency was calculated using equation 4 :

$\operatorname{Removal}(\%)=\frac{\mathrm{C}_{\mathrm{i}}-\mathrm{C}_{\mathrm{f}}}{\mathrm{C}_{\mathrm{i}}} \times 100$ where $\mathrm{C}_{\mathrm{i}}$ and $\mathrm{C}_{\mathrm{f}}$ correspond to the initial and final concentrations $\left(\mathrm{mmol} \mathrm{L}^{-1}\right)$ of the dye, respectively.

\section{Optimization of the EC-DAF process}

In order to optimize the EC-DAF process, a sequential experimental planning was used. Initially, an FFD, $2^{\mathrm{k}-\mathrm{p}}$ was applied, followed by a CCRD. The first planning is part of the evaluation of the significant independent variables $(p<0.05)$. On the other hand, it is used for the determination of the optimal conditions, according to the working range studied, of the aforementioned system. The evaluation of the results obtained was carried out in the software Statistica, version 7.0. ${ }^{34}$ The determination of the statistically significant independent variables by the FFD of two levels occurred with 5 central points and 16 factorial tests. The factors investigated were: $\mathrm{EP}, \mathrm{ES}, \mathrm{t}, \mathrm{pH}_{\mathrm{i}}, \mathrm{PD}$, and P. The CCRD for the purpose of optimizing the EF-DAF system and thus reducing costs, showcased 51 tests with 12 axial points $(\alpha)$ and 7 center points. The response variables evaluated were: color, $\mathrm{pH}_{\mathrm{f}}$, turbidity and removal rate.

The equations proposed by Rodrigues and Iemma, ${ }^{35}$ equations 5 and 6 , which evaluate the similarity between the experimental and the predicted response, were used to validate the predictive model.

$$
\begin{aligned}
& E_{\text {adjustment }}=Y-\hat{Y} \\
& E_{\text {relative }}=\frac{E_{\text {adjustment }}}{Y} \times 100
\end{aligned}
$$

where $Y$ corresponds to the experimental value and $\hat{Y}$ the response foreseen by the model.

\section{Desirability function (DF)}

This function has the objective to show the best values for each variable to be analyzed by means of the CCRD, if it is more of a response variable, in which the function $\left(\mathrm{df}_{\mathrm{i}}\right)$ is based on a numerical range of $0-1$, where 1 and 0 mean, respectively, the maximum and minimum levels of desirability, according to the equations 7,8 , and $9 . .^{36,37}$

$$
\begin{aligned}
& \left(\mathrm{df}_{\mathrm{i}}\right)=\left(\frac{\mathrm{U}-\alpha}{\beta-\alpha}\right)^{\mathrm{w}_{\mathrm{i}}}, \alpha \leq \mathrm{U} \leq \beta \\
& \left(\mathrm{df}_{\mathrm{i}}\right)=1, \mathrm{U}>\beta \\
& \left(\mathrm{df}_{\mathrm{i}}\right)=0, \mathrm{U}<\alpha
\end{aligned}
$$

In equation 7, $\alpha$ and $\beta$ are the lowest and highest values, respectively (obtained from outcome $\mathrm{U}$ ) and $\mathrm{w}_{\mathrm{i}}$ is the level of importance. The individual desirability scores for the 
predicted values of each dependent variable are combined with the DF function by means of their geometric means for all values other than $\left(\mathrm{df}_{\mathrm{i}}\right) .^{38}$

\section{Faradaic efficiency and energy consumption}

The faradaic or current efficiency $(\varphi)$ is a parameter based on the experimental and theoretical anode mass ratio (equation 10). The experimental value $\left(\mathrm{m}_{\mathrm{e}}\right)$ is determined by measuring the anodic mass loss during the experiment (amount of aluminum dissolved), and the corresponding theoretical value $\left(\mathrm{m}_{\mathrm{t}}\right)$ by the Faraday equation (equation 11). Energy consumption $\left(E_{c}\right)$ in the reactor was expressed by equation $12 .{ }^{25,39}$

In these equations, $\mathrm{z}$ is the charge of the metal ion ( 3 for $\mathrm{Al}$ ), F is Faraday's constant $\left(96,485 \mathrm{C} \mathrm{mol}^{-1}\right), \mathrm{m}_{\mathrm{e}}$ is the experimentally observed mass (g), I is the current intensity (A), $t$ is the electrolysis time (s), $\mathrm{M}$ is the molar mass of the metal $\left(\mathrm{g} \mathrm{mol}^{-1}\right), \mathrm{U}$ is the applied potential $(\mathrm{V})$, and $\mathrm{V}$ is the volume $(\mathrm{L})$ of the treated effluent.

$\varphi(\%)=\frac{\mathrm{z} \times \mathrm{F} \times \mathrm{m}_{\mathrm{e}}}{\mathrm{I} \times \mathrm{t} \times \mathrm{M}} \times 100$

$\mathrm{m}_{\mathrm{t}}=\frac{\mathrm{i} \times \mathrm{t} \times \mathrm{M}}{\mathrm{z} \times \mathrm{F}}$

$$
\mathrm{E}_{\mathrm{c}}=\frac{\mathrm{U} \times \mathrm{i} \times \mathrm{t}}{\mathrm{V}}
$$

\section{Results and Discussion}

\section{Fractional factorial design (FFD)}

The FFD was necessary for performing an exploratory analysis and thus select significant independent variables $(p<0.05)$, in addition to adjusting the working ranges for each independent variable..$^{35}$ The results and characteristics of MB solutions are presented in Table 2.

Marked variations in responses occurred due to the variability presented in the statistical assessment of the EF-DAF system. It is important to note that trials 7 (79.3\%) and $8(93.6 \%)$ had higher removal rates. In addition, their experimental conditions differed in EP and PD $(p<0.05)$, thus showing the importance of these parameters in the process.

Color is associated with the absorption (or emission) of part of the electromagnetic radiation due to the presence of dissolved materials. In this context, it is noted that the initial solutions of this study have color due to the presence of MB. High removal values were expected to show low color units; however, this was not the case when no further filtration was performed. Due to the variability of the study,

Table 2. Variables evaluated through FFD

\begin{tabular}{|c|c|c|c|c|c|c|c|c|c|c|}
\hline Essay & $\mathrm{EP}^{\mathrm{a}} / \mathrm{u}$ & $\mathrm{ES}^{\mathrm{b}, \mathrm{c}} / \mathrm{m}$ & $t^{\mathrm{d}, \mathrm{e}} / \mathrm{s}$ & $\mathrm{pH}_{\mathrm{i}}^{\mathrm{f}}$ & $\mathrm{PD}^{\mathrm{g}} / \mathrm{V}$ & $\mathrm{P}^{\mathrm{h}} / \mathrm{MPa}$ & $\mathrm{Col}^{\mathrm{i}} / \mathrm{uH}$ & $\mathrm{pH}_{\mathrm{f}}^{\mathrm{j}}$ & Turk $^{\text {k NTU }}$ & $\operatorname{Re}^{1} / \%$ \\
\hline 1 & $-1(1)^{\mathrm{m}}$ & $-1(1)$ & $-1(1.8)$ & $-1(2)$ & $-1(2)$ & $-1(0)$ & 56.1 & 2.14 & 0.70 & 49.5 \\
\hline 2 & $+1(3)$ & $-1(1)$ & $-1(1.8)$ & $-1(2)$ & $-1(2)$ & $-1(0)$ & 147 & 4.32 & 12.6 & 46.0 \\
\hline 3 & $-1(1)$ & $+1(3)$ & $-1(1.8)$ & $-1(2)$ & $+1(30)$ & $+1(0.4)$ & 142 & 2.35 & 20.8 & 48.7 \\
\hline 4 & $+1(3)$ & $+1(3)$ & $-1(1.8)$ & $-1(2)$ & $-1(2)$ & $+1(0.4)$ & 78.3 & 2.32 & 3.00 & 42.5 \\
\hline 5 & $-1(1)$ & $-1(1)$ & $+1(18)$ & $-1(2)$ & $-1(2)$ & $+1(0.4)$ & 528 & 5.25 & 57.0 & 55.2 \\
\hline 6 & $+1(3)$ & $-1(1)$ & $+1(18)$ & $-1(2)$ & $-1(2)$ & $+1(0.4)$ & 104 & 4.56 & 5.90 & 58.7 \\
\hline 7 & $-1(1)$ & $+1(3)$ & $+1(18)$ & $-1(2)$ & $-1(2)$ & $-1(0)$ & 36.7 & 2.32 & 2.90 & 79.3 \\
\hline 8 & $+1(3)$ & $+1(3)$ & $+1(18)$ & $-1(2)$ & $+1(30)$ & $-1(0)$ & 376 & 4.48 & 1.32 & 93.6 \\
\hline 9 & $-1(1)$ & $-1(1)$ & $-1(1.8)$ & $+1(9)$ & $-1(2)$ & $+1(0.4)$ & 113 & 9.20 & 3.10 & 18.0 \\
\hline 10 & $+1(3)$ & $-1(1)$ & $-1(1.8)$ & $+1(9)$ & $+1(30)$ & $+1(0.4)$ & 105 & 8.50 & 2.50 & 1.25 \\
\hline 11 & $-1(1)$ & $+1(3)$ & $-1(1.8)$ & $+1(9)$ & $+1(30)$ & $-1(0)$ & 71.5 & 8.49 & 3.10 & 31.0 \\
\hline 12 & $+1(3)$ & $+1(3)$ & $-1(1.8)$ & $+1(9)$ & $-1(2)$ & $-1(0)$ & 60.3 & 8.22 & 0.69 & 44.6 \\
\hline 13 & $-1(1)$ & $-1(1)$ & $+1(18)$ & $+1(9)$ & $-1(2)$ & $-1(0)$ & 251 & 9.25 & 19.3 & 28.7 \\
\hline 14 & $+1(3)$ & $-1(1)$ & $+1(18)$ & $+1(9)$ & $-1(2)$ & $-1(0)$ & 45.8 & 8.75 & 0.10 & 27.0 \\
\hline 15 & $-1(1)$ & $+1(3)$ & $+1(18)$ & $+1(9)$ & $-1(2)$ & $+1(0.4)$ & 101 & 7.68 & 1.98 & 31.3 \\
\hline 16 & $+1(3)$ & $+1(3)$ & $+1(18)$ & $+1(9)$ & $+1(30)$ & $+1(0.4)$ & 260 & 8.81 & 16.3 & 48.5 \\
\hline $17(C)^{n}$ & $0(2)$ & $0(2)$ & $0(9.9)$ & $0(5.5)$ & $0(16)$ & $0(0.2)$ & 147 & 8.73 & 6.60 & 18.4 \\
\hline $18(\mathrm{C})$ & $0(2)$ & $0(2)$ & $0(9.9)$ & $0(5.5)$ & $0(16)$ & $0(0.2)$ & 141 & 7.83 & 6.10 & 49.4 \\
\hline 19(C) & $0(2)$ & $0(2)$ & $0(9.9)$ & $0(5.5)$ & $0(16)$ & $0(0.2)$ & 237 & 8.40 & 8.50 & 18.7 \\
\hline $20(\mathrm{C})$ & $0(2)$ & $0(2)$ & $0(9.9)$ & $0(5.5)$ & $0(16)$ & $0(0.2)$ & 235 & 8.50 & 8.60 & 53.4 \\
\hline $21(\mathrm{C})$ & $0(2)$ & $0(2)$ & $0(9.9)$ & $0(5.5)$ & $0(16)$ & $0(0.2)$ & 61.6 & 9.09 & 7.40 & 67.6 \\
\hline
\end{tabular}

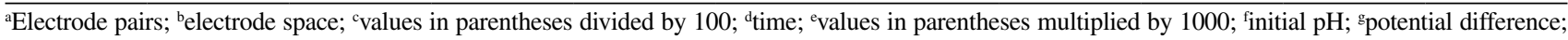
${ }^{\mathrm{h}}$ pressure; ${ }^{\mathrm{i}}$ color; ${ }^{\mathrm{j}}$ final $\mathrm{pH}$; ${ }^{\mathrm{k}}$ turbidity; ${ }^{\mathrm{l}}$ removal rate; ${ }^{\mathrm{m}}$ values in parentheses correspond to experimental conditions; ${ }^{\mathrm{n}}$ central point. NTU: nephelometric turbidity unit. 
the results obtained (Table 2) show atypical experimental conditions, although foreseen in an experimental planning with high number of variables.

In experiment 5, for instance, the $\mathrm{pH}_{\mathrm{i}}$ was 2 and had a $302 \mathrm{uH}$ color. After EC-DAF treatment, the color increased to $528 \mathrm{uH}$, even with a $55.2 \%$ dye removal. If we compare trials 5 and 7, we can see that the difference in experimental conditions is in ES and P. These parameters provided very distinct results for color $(528 \mathrm{uH} ; 36.7 \mathrm{uH})$ and turbidity (57 NTU; 2.9 nephelometric turbidity unit (NTU)). Possibly, the marked difference in the color of the solutions is linked to the presence of dissolved air pressure $(\mathrm{P})$.

According to the National Environment Council (CONAMA in its acronym in Portuguese), ${ }^{40,41}$ there is no tolerable limit for the disposal of dyes from anthropic sources. However, depending on the class of the receiving bed, it is permitted up to $100 \mathrm{NTU}$ (turbidity), $75 \mathrm{uH}$ (color) (Table 2), and $3.7 \times 10^{-3}-5.6 \times 10^{-2} \mathrm{mmol} \mathrm{L}^{-1}$ dissolved aluminum. In the search for an evolution in the answers obtained and that met the local legislation, were conducted filtrations in the resulting solutions. The values of the color and turbidity variables in trials 5, 7 and 8 improve to $192 ; 28.1$ and $37.4 \mathrm{uH}$ (color) and $8.3 ; 1.48 ; 1.18 \mathrm{NTU}$ (turbidity), respectively. It is understandable that experiment 5 displayed a high value of color, as the removal of the dye was only $55.2 \%$. The fraction of aluminum that appears insoluble, responsible for increasing color and turbidity after $\mathrm{EF}$, can be removed by filtration. The soluble part of aluminum is very low and

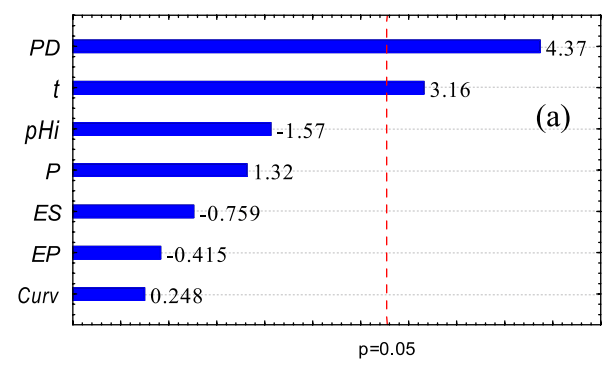

Standardized Effect Estimate (Absolute Value)

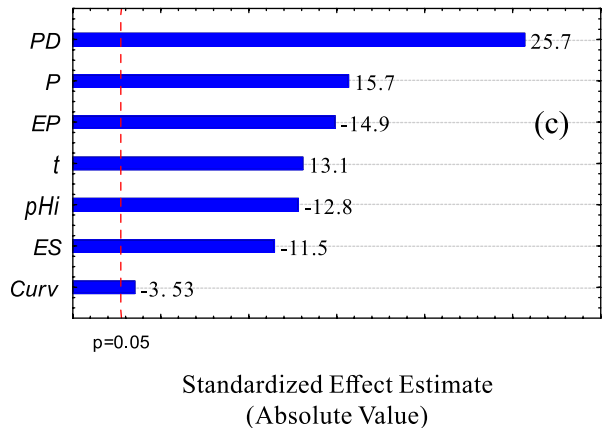

does not contribute to the color, being $1.1 \times 10^{-3} \mathrm{mmol} \mathrm{L}^{-1}$ at $\mathrm{pH} 6.3 .^{42}$

According to the Pareto graph (Figure 2) for color response, only the independent variables $t$ and $\mathrm{PD}$ were significant $(p<0.05)$. Such results indicate that if there is a slight increase in the working range for these parameters, the model showcases statistical significance. The effect of curvature was not significant in this case, indicating a possible linear model.

Regarding $\mathrm{pH}_{\mathrm{f}}$, only the EP and $\mathrm{P}$ factors were not significant $(p<0.05)$. The curvature was significant, indicating a possible quadratic model. As for turbidity, all independent variables were significant $(p<0.05)$, where the positive effects are present in PD, $\mathrm{P}, \mathrm{t}$, and the negative effects appear in $\mathrm{EP}, \mathrm{pH}_{\mathrm{i}}$, and $\mathrm{ES}$. As in the study of $\mathrm{pH}_{\mathrm{f}}$, a quadratic model viability for turbidity is observed. The analysis of the removal percentage showed statistical significance only for the $\mathrm{pH}_{\mathrm{i}}$ factor, with an average of $90 \%$ reliability level.

In order to observe the synergy between the factors, with the possibility of establishing the optimal conditions, it was necessary the execution of a central composite rotational design (CCRD). In this study, all the independent variables were maintained because they had statistical significance.

\section{Central composite rotational design (CCRD)}

Table 3 shows the results of CCRD for the removal of MB. Experiments $24(95.1 \%)$ and $39(94.5 \%)$ proved
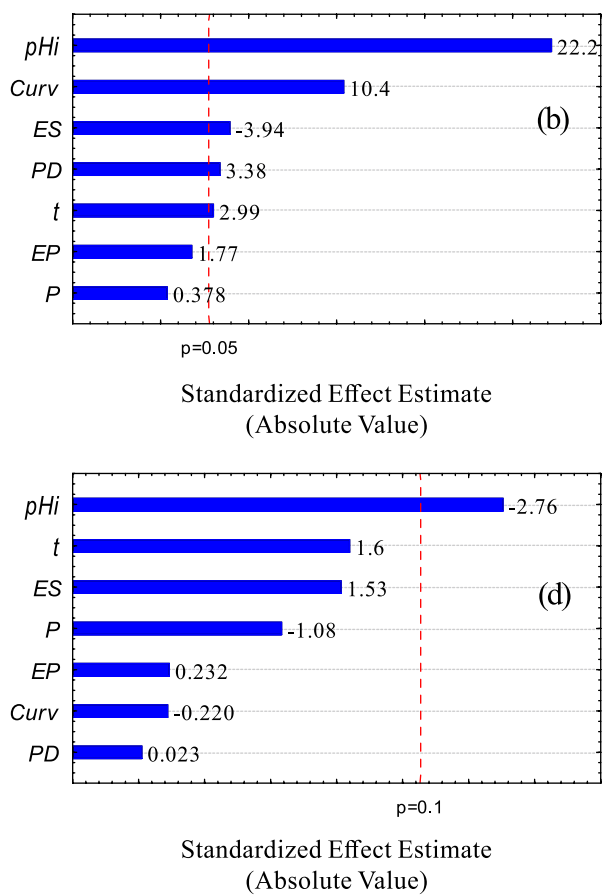

Figure 2. Pareto plot for FFD, (a) color, (b) final $\mathrm{pH}$, (c) turbidity, (d) removal rate. Electrode pairs (EP), electrode space (ES), time (t), initial $\mathrm{pH}\left(\mathrm{pH}_{\mathrm{i}}\right)$, potential difference $(\mathrm{PD})$, dissolved air pressure $(\mathrm{P})$, curvature (Curv). 
to be adequate regarding removal rates. Test 39 , in spite of its shorter reaction time, showcased an important efficiency. The high acidity of the medium caused an intense production of bubbles promoting an appropriate removal

Table 3. Response variables evaluated using CCRD in treatment of methylene blue (MB) solution

\begin{tabular}{|c|c|c|c|c|c|c|c|c|c|c|}
\hline Essay & $\mathrm{EP}^{\mathrm{a}} / \mathrm{u}$ & $\mathrm{ES}^{\mathrm{b}, \mathrm{c}} / \mathrm{m}$ & $\mathrm{t}^{\mathrm{d}, \mathrm{e} / \mathrm{s}}$ & $\mathrm{pH}_{\mathrm{i}}^{\mathrm{f}}$ & $\mathrm{PD}^{\mathrm{g}} / \mathrm{V}$ & $\mathrm{P}^{\mathrm{h}} / \mathrm{MPa}$ & $\mathrm{Col}^{\mathrm{i}} / \mathrm{uH}$ & $\mathrm{pH}_{\mathrm{f}}{ }^{\mathrm{j}}$ & Turk $^{\mathrm{k}} / \mathrm{NTU}$ & $\operatorname{Re}^{1} / \%$ \\
\hline 1 & $-1(1)$ & $-1(1)^{\mathrm{m}}$ & $-1(1.8)$ & $-1(2)$ & $-1(2)$ & $-1(0)$ & 27.3 & 2.35 & -0.10 & 51.2 \\
\hline 2 & $-1(1)$ & $-1(1)$ & $-1(1.8)$ & $-1(2)$ & $+1(30)$ & $+1(0.5)$ & 116 & 4.46 & 20.7 & 68.7 \\
\hline 3 & $-1(1)$ & $-1(1)$ & $-1(1.8)$ & $+1(9)$ & $-1(2)$ & $+1(0.5)$ & 39.1 & 7.78 & 12.3 & 34.3 \\
\hline 4 & $-1(1)$ & $-1(1)$ & $-1(1.8)$ & $+1(9)$ & $+1(30)$ & $-1(0)$ & 95.9 & 9.20 & 3.80 & 2.08 \\
\hline 5 & $-1(1)$ & $-1(1)$ & $+1(18)$ & $-1(2)$ & $-1(2)$ & $+1(0.5)$ & 391 & 4.64 & 8.23 & 62.1 \\
\hline 6 & $-1(1)$ & $-1(1)$ & $+1(18)$ & $-1(2)$ & $+1(30)$ & $-1(0)$ & 250 & 4.50 & 74.7 & 77.5 \\
\hline 7 & $-1(1)$ & $-1(1)$ & $+1(18)$ & $+1(9)$ & $-1(2)$ & $-1(0)$ & 122 & 9.48 & 4.03 & 17.6 \\
\hline 8 & $-1(1)$ & $-1(1)$ & $+1(18)$ & $+1(9)$ & $+1(30)$ & $+1(0.5)$ & 6.56 & 8.55 & 36.7 & 36.3 \\
\hline 9 & $-1(1)$ & $+1(3)$ & $-1(1.8)$ & $-1(2)$ & $-1(2)$ & $+1(0.5)$ & 74.6 & 2.29 & 1.97 & 57.1 \\
\hline 10 & $-1(1)$ & $+1(3)$ & $-1(1.8)$ & $-1(2)$ & $+1(30)$ & $-1(0)$ & 64.9 & 2.91 & 21.0 & 74.7 \\
\hline 11 & $-1(1)$ & $+1(3)$ & $-1(1.8)$ & $+1(9)$ & $-1(2)$ & $-1(0)$ & 25.3 & 8.51 & -0.13 & 22.7 \\
\hline 12 & $-1(1)$ & $+1(3)$ & $-1(1.8)$ & $+1(9)$ & $+1(30)$ & $+1(0.5)$ & 38.0 & 7.96 & 4.23 & 35.1 \\
\hline 13 & $-1(1)$ & $+1(3)$ & $+1(18)$ & $-1(2)$ & $-1(2)$ & $-1(0)$ & 59.0 & 4.46 & 0.59 & 34.0 \\
\hline 14 & $-1(1)$ & $+1(3)$ & $+1(18)$ & $-1(2)$ & $+1(30)$ & $+1(0.5)$ & 422 & 4.63 & 76.7 & 75.8 \\
\hline 15 & $-1(1)$ & $+1(3)$ & $+1(18)$ & $+1(9)$ & $-1(2)$ & $+1(0.5)$ & 51.3 & 8.84 & 3.77 & 16.6 \\
\hline 16 & $-1(1)$ & $+1(3)$ & $+1(18)$ & $+1(9)$ & $+1(30)$ & $-1(0)$ & 197 & 9.22 & 39.7 & 18.2 \\
\hline 17 & $+1(3)$ & $-1(1)$ & $-1(1.8)$ & $-1(2)$ & $-1(2)$ & $+1(0.5)$ & 18.8 & 2.25 & 4.30 & 54.9 \\
\hline 18 & $+1(3)$ & $-1(1)$ & $-1(1.8)$ & $-1(2)$ & $+1(30)$ & $-1(0)$ & 131 & 4.55 & 55.0 & 86.7 \\
\hline 19 & $+1(3)$ & $-1(1)$ & $-1(1.8)$ & $+1(9)$ & $-1(2)$ & $-1(0)$ & 45.9 & 9.25 & 4.73 & 9.31 \\
\hline 20 & $+1(3)$ & $-1(1)$ & $-1(1.8)$ & $+1(9)$ & $+1(30)$ & $+1(0.5)$ & 64.1 & 8.88 & 12.6 & 23.3 \\
\hline 21 & $+1(3)$ & $-1(1)$ & $+1(18)$ & $-1(2)$ & $-1(2)$ & $-1(0)$ & 104 & 4.41 & 8.30 & 51.7 \\
\hline 22 & $+1(3)$ & $-1(1)$ & $+1(18)$ & $-1(2)$ & $+1(30)$ & $+1(0.5)$ & 2776 & 4.85 & 162 & 44.4 \\
\hline 23 & $+1(3)$ & $-1(1)$ & $+1(18)$ & $+1(9)$ & $-1(2)$ & $+1(0.5)$ & 46.7 & 9.39 & 20.0 & 31.3 \\
\hline 24 & $+1(3)$ & $-1(1)$ & $+1(18)$ & $+1(9)$ & $+1(30)$ & $-1(0)$ & 474 & 6.70 & 42.7 & 95.1 \\
\hline 25 & $+1(3)$ & $+1(3)$ & $-1(1.8)$ & $-1(2)$ & $-1(2)$ & $-1(0)$ & 41.6 & 2.46 & 2.30 & 50.0 \\
\hline 26 & $+1(3)$ & $+1(3)$ & $-1(1.8)$ & $-1(2)$ & $+1(30)$ & $+1(0.5)$ & 79.3 & 4.30 & 0.42 & 88.8 \\
\hline 27 & $+1(3)$ & $+1(3)$ & $-1(1.8)$ & $+1(9)$ & $-1(2)$ & $+1(0.5)$ & 29.8 & 8.04 & 8.43 & 1.8 .3 \\
\hline 28 & $+1(3)$ & $+1(3)$ & $-1(1.8)$ & $+1(9)$ & $+1(30)$ & $-1(0)$ & 79.2 & 9.28 & 6.70 & 16.4 \\
\hline 29 & $+1(3)$ & $+1(3)$ & $+1(18)$ & $-1(2)$ & $-1(2)$ & $+1(0.5)$ & 70.0 & 4.54 & 2.10 & 51.1 \\
\hline 30 & $+1(3)$ & $+1(3)$ & $+1(18)$ & $-1(2)$ & $+1(30)$ & $-1(0)$ & 270 & 4.55 & 69.0 & 73.4 \\
\hline 31 & $+1(3)$ & $+1(3)$ & $+1(18)$ & $+1(9)$ & $-1(2)$ & $-1(0)$ & 104 & 9.42 & 5.83 & 18.9 \\
\hline 32 & $+1(3)$ & $+1(3)$ & $+1(18)$ & $+1(9)$ & $+1(30)$ & $+1(0.5)$ & 75.8 & 8.88 & 22.3 & 43.6 \\
\hline 33 & $-1(1)$ & $0(2)$ & $0(9.9)$ & $0(5.5)$ & $0(16)$ & $0(0.25)$ & 104 & 6.01 & 7.70 & 26.0 \\
\hline 34 & $+2(4)$ & $0(2)$ & $0(9.9)$ & $0(5.5)$ & $0(16)$ & $0(0.25)$ & 207 & 8.00 & 23.7 & 39.0 \\
\hline 35 & $0(2)$ & $-1(1)$ & $0(9.9)$ & $0(5.5)$ & $0(16)$ & $0(0.25)$ & 225 & 8.30 & 25.3 & 33.2 \\
\hline 36 & $0(2)$ & $+2(4)$ & $0(9.9)$ & $0(5.5)$ & $0(16)$ & $0(0.25)$ & 76.4 & 8.63 & 23.0 & 18.0 \\
\hline 37 & $0(2)$ & $0(2)$ & $-1.1(0.9)$ & $0(5.5)$ & $0(16)$ & $0(0.25)$ & 47.9 & 7.20 & 5.60 & 21.4 \\
\hline 38 & $0(2)$ & $0(2)$ & $+2.4(29)$ & $0(5.5)$ & $0(16)$ & $0(0.25)$ & 61.6 & 7.06 & 51.0 & 38.1 \\
\hline 39 & $0(2)$ & $0(2)$ & $0(9.9)$ & $-1.3(1)$ & $0(16)$ & $0(0.25)$ & 142 & 1.56 & 86.3 & 94.5 \\
\hline 40 & $0(2)$ & $0(2)$ & $0(9.9)$ & $+1(9)$ & $0(16)$ & $0(0.25)$ & 129 & 8.85 & 4.83 & 20.4 \\
\hline 41 & $0(2)$ & $0(2)$ & $0(9.9)$ & $0(5.5)$ & $-1.1(1)$ & $0(0.25)$ & 99.6 & 8.60 & 8.60 & 20.8 \\
\hline 42 & $0(2)$ & $0(2)$ & $0(9.9)$ & $0(5.5)$ & $+2.3(32)$ & $0(0.25)$ & 233 & 8.23 & 22.3 & 42.9 \\
\hline 43 & $0(2)$ & $0(2)$ & $0(9.9)$ & $0(5.5)$ & $0(16)$ & $-1(0)$ & 124 & 8.16 & 45.0 & 35.1 \\
\hline 44 & $0(2)$ & $0(2)$ & $0(9.9)$ & $0(5.5)$ & $0(16)$ & $+1.4(0.6)$ & 172 & 7.69 & 19.7 & 43.3 \\
\hline $45(C)^{n}$ & $0(2)$ & $0(2)$ & $0(9.9)$ & $0(5.5)$ & $0(16)$ & $0(0.25)$ & 210 & 8.22 & 38.0 & 36.4 \\
\hline $46(C)$ & $0(2)$ & $0(2)$ & $0(9.9)$ & $0(5.5)$ & $0(16)$ & $0(0.25)$ & 199 & 6.68 & 19.0 & 36.7 \\
\hline $47(\mathrm{C})$ & $0(2)$ & $0(2)$ & $0(9.9)$ & $0(5.5)$ & $0(16)$ & $0(0.25)$ & 167 & 8.58 & 44.7 & 30.9 \\
\hline $48(C)$ & $0(2)$ & $0(2)$ & $0(9.9)$ & $0(5.5)$ & $0(16)$ & $0(0.25)$ & 164 & 8.42 & 48.3 & 31.4 \\
\hline $49(\mathrm{C})$ & $0(2)$ & $0(2)$ & $0(9.9)$ & $0(5.5)$ & $0(16)$ & $0(0.25)$ & 198 & 8.45 & 22.0 & 34.4 \\
\hline $50(\mathrm{C})$ & $0(2)$ & $0(2)$ & $0(9.9)$ & $0(5.5)$ & $0(16)$ & $0(0.25)$ & 207 & 7.97 & 26.7 & 30.9 \\
\hline $51(\mathrm{C})$ & $0(2)$ & $0(2)$ & $0(9.9)$ & $0(5.5)$ & $0(16)$ & $0(0.25)$ & 157 & 7.73 & 13.1 & 33.1 \\
\hline
\end{tabular}

${ }^{\mathrm{a}}$ Electrode pairs; ${ }^{\mathrm{b}}$ electrode space; ${ }^{\mathrm{c}}$ values in parentheses divided by 100 ; ${ }^{\mathrm{d}}$ time; ${ }^{\mathrm{e}}$ values in parentheses multiplied by 1000 ; ${ }^{\text {initial }} \mathrm{pH}$; ${ }^{\mathrm{g}}$ potential difference; ${ }^{\mathrm{h}}$ pressure; ${ }^{\mathrm{i}}$ color; ${ }^{\mathrm{j}}$ final $\mathrm{pH}$; ${ }^{\mathrm{k}}$ turbidity; ${ }^{1}$ removal rate; ${ }^{\mathrm{m}}$ values in parentheses correspond to experimental conditions; ${ }^{\mathrm{n}} \mathrm{central}$ point. 
rate as to the transparency gain of the system under study. This effect may be related to two factors: the spontaneity that aluminum has in losing electrons in the acid medium producing hydrogen and the formation of $\mathrm{HClO}$. This process results in the degradation of $\mathrm{MB} \cdot{ }^{24,43} \mathrm{pH}$ is a highly relevant variable in the EC studies, because it interferes with the solubility of aluminum compounds and, when they occur at neutral $\mathrm{pH}$, there is an increase in energy consumption with low removal efficiency. ${ }^{44}$ Conditions at $\mathrm{pH}<5$ become unfavorable due to the need to correct acidity for release in water bodies. ${ }^{25,40}$

As stated earlier, the main processes occurring during EC treatment are the electrolytic generation of the coagulant and its interactions with the polluting agent, causing its destabilization and subsequent aggregation. Simultaneously, $\mathrm{H}_{2(\mathrm{~g})}$ microbubbles produced at the cathode promote the flotation of most flakes, separating the particles from the wastewater. However, this whole process is effectively dependent on $\mathrm{pH}$. Depending on the $\mathrm{pH}$ range, the aluminum cations undergo spontaneous hydrolysis, forming hydroxide and polyhydroxides, such as: $\mathrm{Al}(\mathrm{OH})^{2+} ; \mathrm{Al}(\mathrm{OH})_{2}{ }^{+}$; $\mathrm{Al}_{2}(\mathrm{OH})_{2}{ }^{4+} ; \mathrm{Al}(\mathrm{OH})_{4}{ }^{-} ; \mathrm{Al}_{6}(\mathrm{OH})_{15}{ }^{3+} ; \mathrm{Al}_{7}(\mathrm{OH})_{17}{ }^{4+} ; \mathrm{Al}_{8}(\mathrm{OH})_{20}{ }^{4+}$; $\mathrm{Al}_{13} \mathrm{O}_{4}(\mathrm{OH})_{24}{ }^{7+}$. At $\mathrm{pH}<5$, the species: $\mathrm{Al}(\mathrm{OH})^{2+}, \mathrm{Al}(\mathrm{OH})_{2}{ }^{+}$ and $\mathrm{Al}\left(\mathrm{H}_{2} \mathrm{O}\right)_{6}{ }^{3+}$ are predominant, and favor the formation of longer polymers, as illustrated by the Figure 3.42,45 As $\mathrm{pH}$ increases, $(\mathrm{pH}$ ca. 5.5) the concentrations of these species decrease, and the traces of $\mathrm{Al}(\mathrm{OH})_{4}^{-}$start being formed in the order of $10^{-7} \mathrm{~mol} \mathrm{~L}^{-1} .{ }^{42}$ Between the $\mathrm{pH}$ levels 5 and 7 , the species $\mathrm{Al}(\mathrm{OH})_{3}$ represents the majority, and at a $\mathrm{pH}$ close to 6, this species has a low water solubility. At pH 8, a small amount of $\mathrm{Al}(\mathrm{OH})_{2}{ }^{+}$still persists, becoming the predominant aluminate after $\mathrm{pH} 8.5 .^{24,42}$

Aluminum ions in their most diverse forms can interact with scattered particles of contrary signals, encapsulating them and forming flakes that can float due to the action of those hydrogen bubbles. As $\mathrm{MB}$ is a cationic dye, ${ }^{46}$ these interactions will not be very effective in an acidic environment ( $\mathrm{pH}$ 's $<5.5$ ), circumstance in which both analyte and aluminum ions showcase positive charges (Figure 3a).

At a $\mathrm{pH}$ close to neutrality, $\mathrm{MB}$ is unprotonated ${ }^{47}$ promoting interactions with hydrogen bonds (Figure $3 \mathrm{~b}$ ) and dipole-dipole (Figure 3d). Under conditions of $\mathrm{pH}>7$, only aluminate, the precursor of the formation of the $\mathrm{Al}_{13} \mathrm{O}_{4}(\mathrm{OH})_{24}{ }^{7+}$ species, ${ }^{48}$ is able to neutralize $\mathrm{MB}$ (Figure $3 \mathrm{c}$ ) by means of electrostatic interactions.

Thus, the formation of aluminum complexes depends on the dynamics of simultaneous electrochemical and chemical

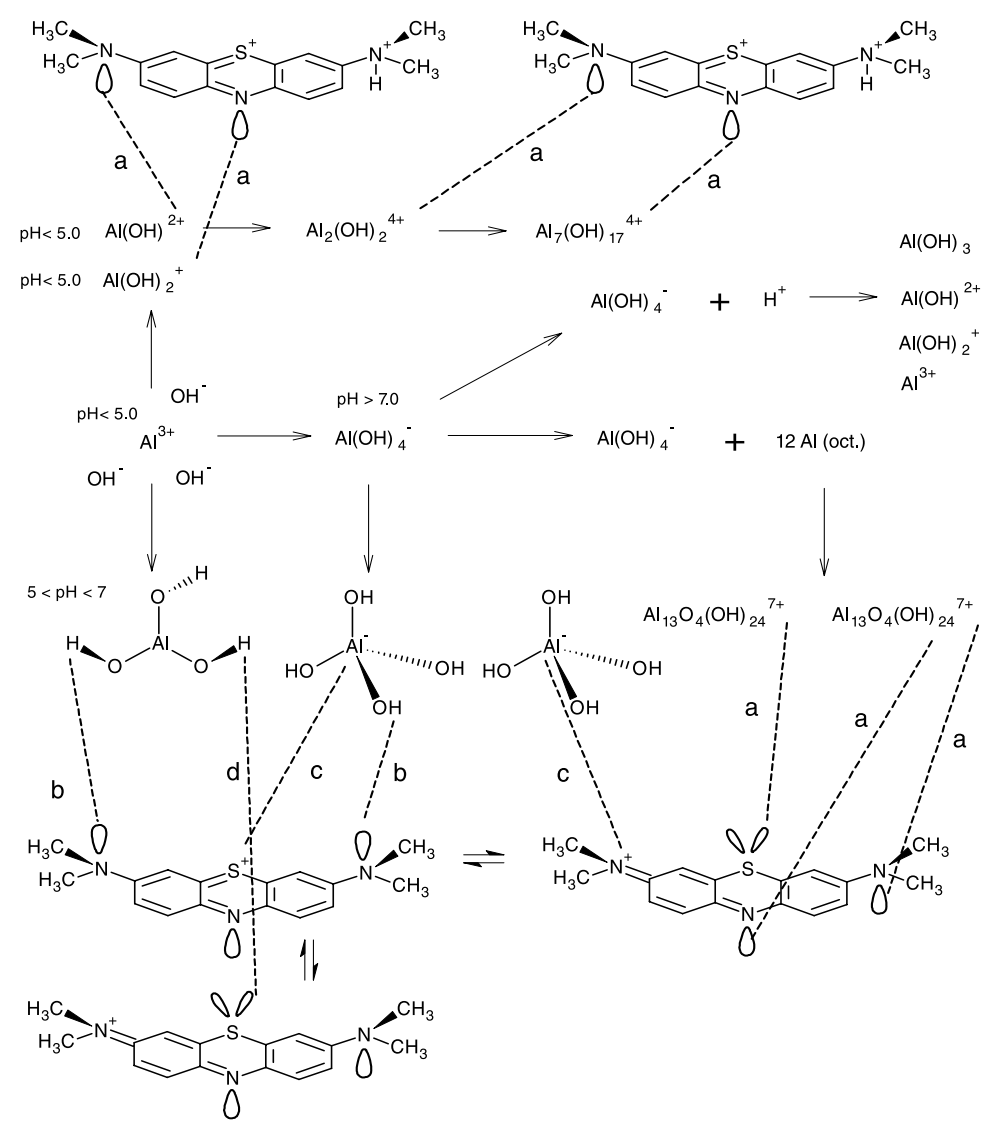

Figure 3. Probable aluminum hydrolysis routes and possible interaction with methylene blue (MB), (a) ion-dipole interactions, (b) hydrogen bonds, (c) electrostatic attraction, (d) dipole-dipole. 
processes and interferes with the change in $\mathrm{pH}$ values. The anodic reduction of water releases hydrogen and favors an increase in $\mathrm{pH}$ (equation 2). On the other hand, there are numerous explanations for the $\mathrm{pH}$ 's reducing, such as the hydrolysis of aluminum species (equations 13-17) and the chemical action of $\mathrm{OH}^{-}$ions generated on the cathode according to equation $18 .^{49}$

$$
\begin{aligned}
& \mathrm{Al}(\mathrm{OH})_{4}{ }^{-}+\mathrm{H}^{+} \rightleftarrows \mathrm{Al}(\mathrm{OH})_{3}+\mathrm{H}_{2} \mathrm{O} \\
& \mathrm{Al}(\mathrm{OH})_{3}+\mathrm{H}^{+} \rightleftarrows \mathrm{Al}(\mathrm{OH})^{+}+\mathrm{H}_{2} \mathrm{O} \\
& \mathrm{Al}(\mathrm{OH})_{2}{ }^{+}+\mathrm{H}^{+} \rightleftarrows \mathrm{Al}(\mathrm{OH})^{2+}+\mathrm{H}_{2} \mathrm{O} \\
& \mathrm{Al}(\mathrm{OH})^{2+}+\mathrm{H}^{+} \rightleftarrows \mathrm{Al}^{3+}+\mathrm{H}_{2} \mathrm{O} \\
& \mathrm{Al}(\mathrm{OH})_{3}+\rightleftarrows \mathrm{Al}^{3+}+3 \mathrm{OH}^{-} \\
& 2 \mathrm{Al}+6 \mathrm{H}_{2} \mathrm{O}+2 \mathrm{OH}^{-} \rightarrow 2 \mathrm{Al}\left(\mathrm{OH}_{4}\right)^{-}+3 \mathrm{H}_{2}
\end{aligned}
$$

Therefore, with the previous considerations in mind, the EC mechanism in aqueous systems is obviously quite complex even for a standard medium. Nevertheless, it can be inferred that the metal ions form their hydroxides species, according to $\mathrm{pH}$, and the $\mathrm{MB}$ is removed by coagulation or sorption motivated by the possible interactions suggested in Figure 3.

Looking for a predictive and adjusted model $(p<0.05)$, it was necessary to perform the analysis of variance (ANOVA) for the responses (Table S1, Supplementary Information (SI) section). Factors with $p<0.05$ correspond to statistically significant independent variables. It is worth noting that a $90 \%$ reliability rate was adopted for the variable removal rate response, where the independent variables and their interactions were considered statistically significant with $p_{\text {value }}<0.1$. A mathematical model for the color variable could not be validated as it did not have a satisfactory adjustment $(P<0.05)$ (Figure S1, SI section). Moreover, it was not possible to consider it since the adjustment error and relative error tests showed divergences above $20 \% 35$ when compared to the data values obtained in the mathematical model and real experimental values (Figure 4).

The variables $\mathrm{pH}_{\mathrm{f}}$ and turbidity showcased satisfactory coefficients of determination with an explanation percentage of 96 and 84\%, respectively (Table S1). It is worth pointing out that both models were predictive for having a nonsignificant lack of adjustment $(p>0.05)$, as well as parametric, for being presented as a normal distribution (Figure S2, SI section). These factors demonstrate that the mathematical model developed for these variables is adequate and predictive, since the values obtained by it provided the experimental values satisfactorily (Figure S1), with the possibility of determining the optimal conditions for the system under study.

However, an inaccuracy is observed for the percentage removal variable. Such imprecision is particularly noted in

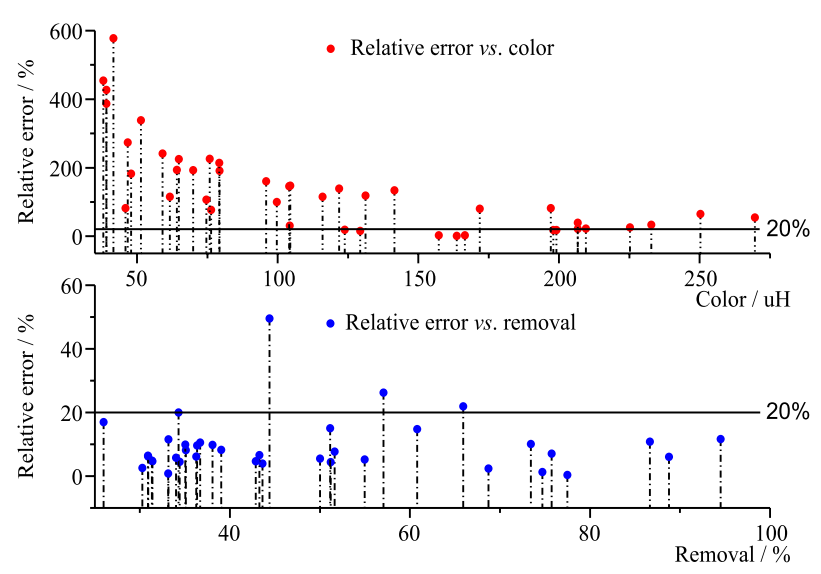

Figure 4. Relative error vs. experimental values for color and removal rate.

the results of ANOVA (Table S1), where this variable shows a significant lack of adjustment for a reliability of $90 \%$.

According to Rodrigues and Iemma ${ }^{35}$ the lack of adjustment is not the determining factor for the development of a predictive model, especially when it is related to the central points, thus reflecting a low value for pure error (Table S1). Therefore, with the use of the equations of error of adjustment and relative error (equations 5 and 6), it was possible to evaluate the possibility of a model for variable removal rate because it showcases a predictive characteristic. The results obtained can be seen in Figure 4. In addition, the coefficient of determination $\left(\mathrm{R}^{2}\right)$ for this variable was able to explain $89 \%$ of the data (Table S1). It is also worth noting that values under or equal to $20 \%{ }^{35}$ obtained by means of the adjustment error certify the predictability of the mathematical model.

When using the adjustment error and relative to evaluate the predictability of the model obtained for the variable removal rate, it was observed that only above $65 \%$ removal values had a difference of $20 \%$ or less (Figure 4). This fact indicated that the model would show predictability only in situations with removal rate greater than $65 \%$. Thus, as the goal of this study was to obtain the maximum removal approaching $100 \%$, the mathematical model proved to be adequate and predictive. ${ }^{35}$

In light of the remarkable results, the regression in the determination of the equations (19,20 and 21) of the models was permissible. They relate the analytical responses to the encoded independent variables (Table S2, SI section). In short, it is possible to understand the scalability potential of the proposed system to be applied at an industrial level.

$\mathrm{pH}_{\mathrm{f}}=7.9+0.38 \mathrm{t}+2.4 \mathrm{pH}_{\mathrm{i}}-1.7 \mathrm{pH}_{\mathrm{i}}^{2}-0.29 \mathrm{t} . \mathrm{pH}_{\mathrm{i}}-$ $0.37 \mathrm{t} . \mathrm{PD}-0.29 \mathrm{pH}_{\mathrm{i}} \cdot \mathrm{PD}$

Turb. $=29-5.8 \mathrm{ES}+14 \mathrm{t}-11 \mathrm{pH}_{\mathrm{i}}+17 \mathrm{PD}-8.9 \mathrm{PD}^{2}+$

$12 \mathrm{t} . \mathrm{PD}-11 \mathrm{pH}_{\mathrm{i}} \cdot \mathrm{PD}$ 
Rem. $(\%)=33+2.1 \mathrm{EP}-3.8 \mathrm{ES}^{2}+0.99 \mathrm{t}-19 \mathrm{pH}_{\mathrm{i}}+$ $16 \mathrm{pH}_{\mathrm{i}}^{2}+7.7 \mathrm{PD}-1.8 \mathrm{PD}^{2}+2.6 \mathrm{P}+2 \mathrm{P}^{2}+0.93 \mathrm{EP} . \mathrm{t}+$ 1.7EP. $\mathrm{pH}_{\mathrm{i}}+$ 1.6EP.PD - 2.8EP.P - 3.1ES.t + 1.6ES.PD + 3.1ES.P + 4.3t. $\mathrm{pH}_{\mathrm{i}}+2.1 \mathrm{t} . \mathrm{PD}-2.4 \mathrm{t} . \mathrm{P}-3.7 \mathrm{pH}_{\mathrm{i}} \cdot \mathrm{PD}+$ 2.4pH $\mathrm{pH}_{\mathrm{i}} \mathrm{P}-2.5 \mathrm{PD} . \mathrm{P}$

where Turb.: turbidity and Rem.: removal.

The interactions between the parameters chosen for the analysis of the response surfaces were determined by evaluating the significant terms $(p<0.05)$. Figure 5 shows the most representative ternary models for the description of the system under study.
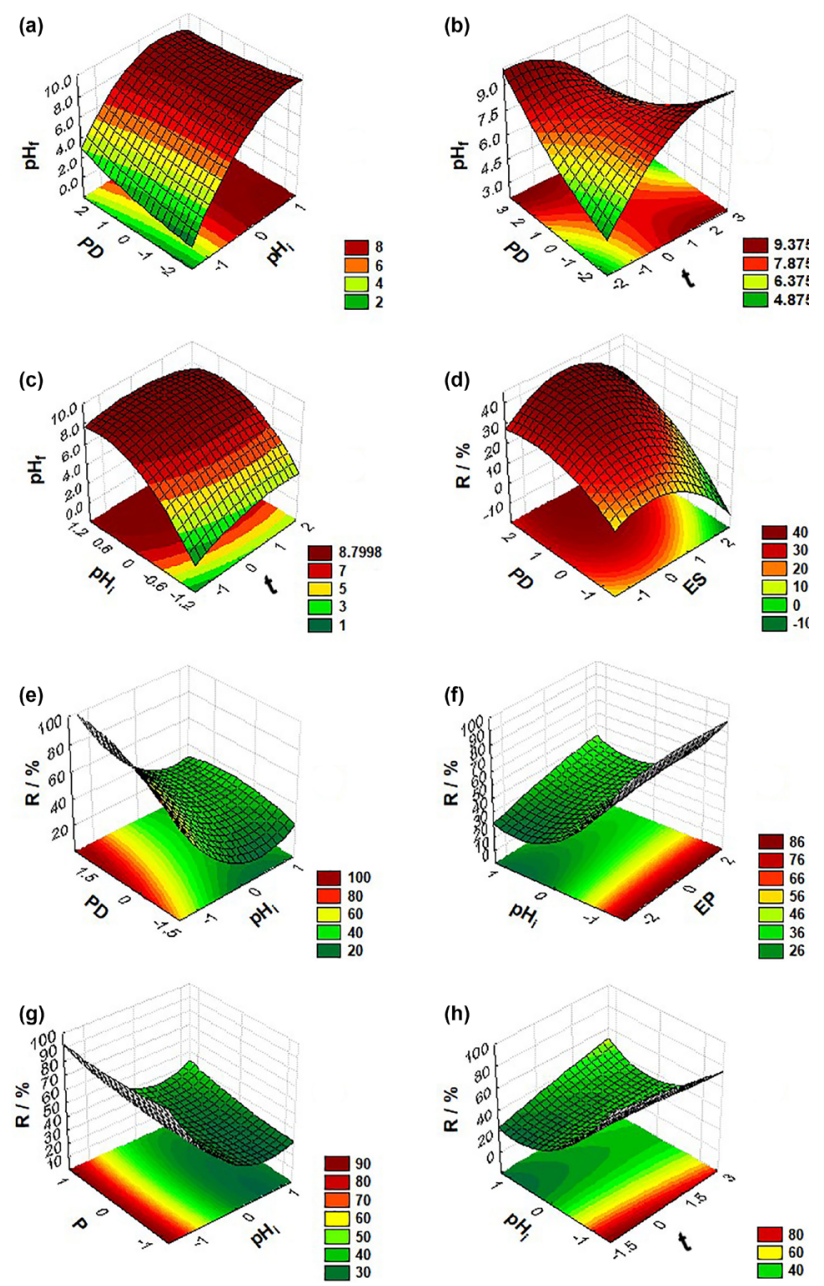

Figure 5. Response surfaces for $\mathrm{pH}_{\mathrm{f}}$ and removal rate: (a) $\mathrm{PD}-\mathrm{pH}_{\mathrm{i}}$; (b) PD-t; (c) $\mathrm{pH}_{\mathrm{i}}$-t ; (d) PD-ES; (e) $\mathrm{PD}_{\mathrm{pH}}$; (f) $\mathrm{pH}_{\mathrm{i}}-\mathrm{EP}$; (g) $\mathrm{P}-\mathrm{pH}_{\mathrm{i}}$; (h) $\mathrm{pH}_{\mathrm{i}}$-t. Electrode pairs (EP), electrode space $(\mathrm{ES})$, time $(\mathrm{t})$, hydrogen potential $(\mathrm{pH})$, potential difference $(\mathrm{PD})$, dissolved air pressure $(\mathrm{P})$. Independent variables are coded and without physical unit.

The $\mathrm{pH}_{\mathrm{f}}$ response increases along with $\mathrm{pH}_{\mathrm{i}}$ elevation, with minimal effect on the change in reaction time. The same behavior is identified in the relationship between $\mathrm{pH}_{\mathrm{i}}$ and $\mathrm{PD}$, demonstrating that the choice of $\mathrm{pH}$ is decisive in the selection of an operating scale in the system. The variation of this parameter throughout the process is directly related to the release of gaseous hydrogen, which raises the $\mathrm{pH}$ when the medium is acidic. In turn, in the alkaline environment, the system acts dynamically in the consumption and production of $\mathrm{OH}^{-}$and a buffering effect on the $\mathrm{pH}$ is observed. ${ }^{24,39}$ The formation of saddle point training in the PD-t group makes it difficult to evaluate the regions of interest, which are situated at restricted intervals between the extremes of the studied interactions (Figure 5b).

The removal rate improves when $\mathrm{pH}<7$ is used. Adsorption and degradation of the dye are essential for process efficiency under acidic conditions. However, the excessively acidic medium is not recommended as mentioned above. Evaluation of the PD-ES interaction indicates that intermediate distances combined with increasing PD values may be more promising in the removal of the dye.

The impact of the other independent variables, although statistically less important when compared to that of the $\mathrm{pH}$, are also important to the process because of their potential to foster the best conditions for the simultaneous optimization of the other dependent variables in this study. Thus, a global desirability is evaluated for the definition of the best-operating conditions of the system, as well as a subsequent validation of the mathematical models obtained via CCRD.

\section{Desirability function (DF)}

In the optimization of the system by the desirability function, it was demonstrated that the best conditions of this study, relative to the independent variables, were 4 pairs of electrodes, $0.025 \mathrm{~m}$ spacing, $12,180 \mathrm{~s}, \mathrm{pH}_{\mathrm{i}}=4$, $\mathrm{PD}=32 \mathrm{~V}$, and absence of dissolved air pressure. The dashed lines on the right side in Figure 6 show the desirable values. The numbers on the left side refer to the results of the optimization of the response variables. The continuous lines at the bottom are the conditions established by the desirability function for the independent variables.

Naturally, the desirable in this study would be to remove $95 \%$ of the dye as shown on the right side of Figure 6. This was possible in CCRD trials 24 and 39. However, the optimization for the desirability function is multivariate and the narrow range of $\mathrm{pH}_{\mathrm{f}}(5-9)$ established by legislation ${ }^{40,41}$ hinders such removal in smaller times and very acidic $\mathrm{pH}$ 's. Thus, in optimization it was possible to predict only $66 \%$ removal for a $\mathrm{pH}_{\mathrm{f}} 6.8$.

The EC covers consecutive steps such as the electrochemical formation of the coagulant, destabilization of pollutants, aggregation of the destabilized phase to form 

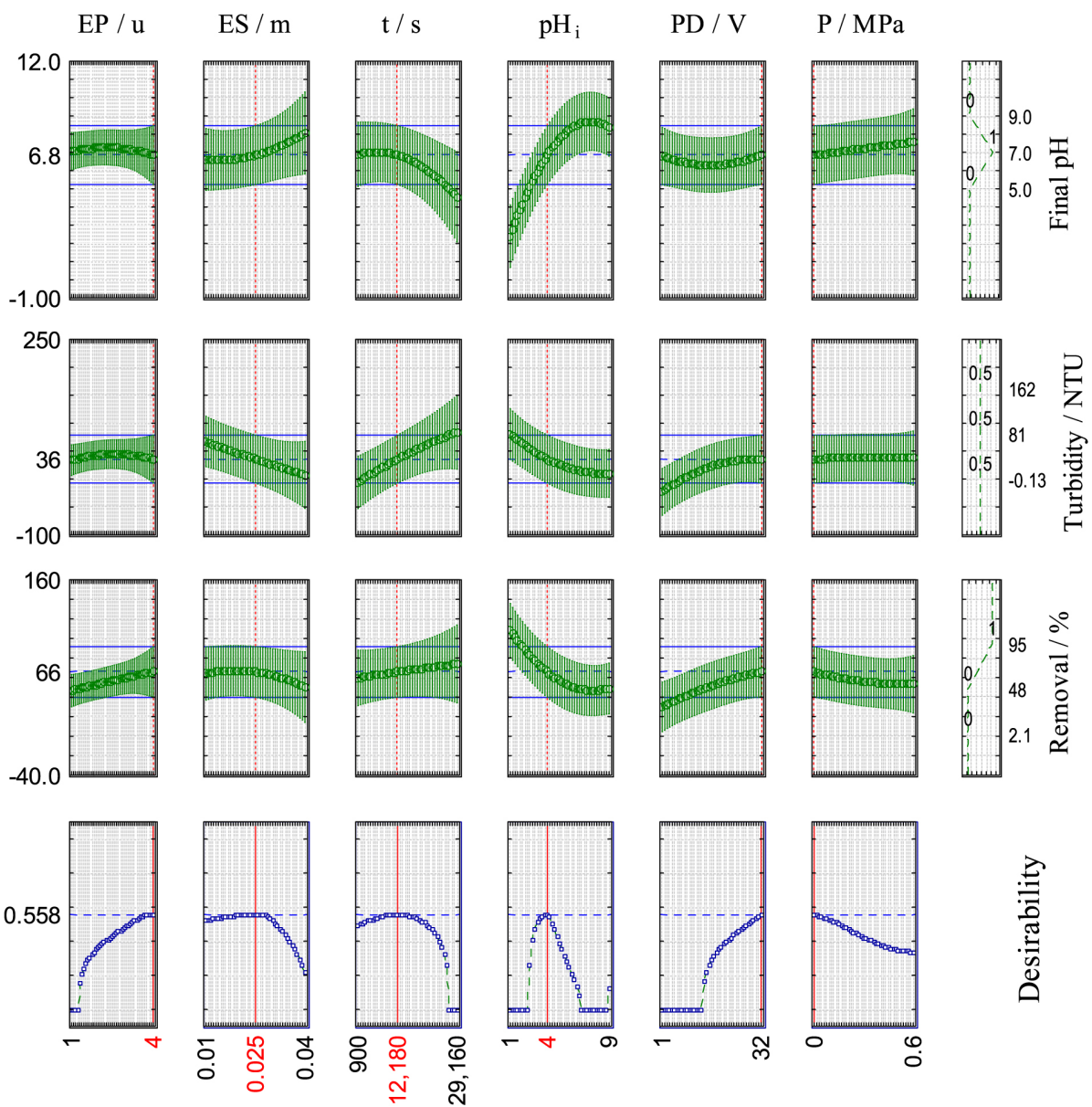

Figure 6. Profiles for predicated values and desirability for $\mathrm{pH}_{\mathrm{f}}$, turbidity and removal rate. Electrode pairs (EP), electrode space (ES), time (t), hydrogen potential $(\mathrm{pH})$, potential difference $(\mathrm{PD})$, dissolved air pressure $(\mathrm{P})$.

flakes and removal by flotation. ${ }^{50} \mathrm{DAF}$ occurs when there is affinity between bubbles and formed colloidal particles. If the flakes formed have low density, they may be dragged to the surface. However, for the application of this technology in water treatment, it is essential to use a coagulant agent in a pre-treatment stage to electrocoagulation..$^{51-54}$ These coagulants can eliminate the double electrical layer around the colloidal particles favoring agglomeration..$^{52} \mathrm{Here}$, this prior treatment was not carried out, because the initial idea was that the coagulant would be originated in situ, exclusively during the corrosion of electrodes.

The effect of the variable pressure, originating from dissolved air, on the removal was registered in Figure 7. Comparisons are made between experiments performed under similar conditions, distinguished only by the absence and presence of dissolved air pressure. It is observed that DAF did not obtain a well-defined contribution in the removal of MB, as it disorganizes the system and the dyecomplex desorption of aluminum is promoted by increasing the turbidity. Therefore, the sequential planning strategy with subsequent optimization indicates a system with no dissolved air in the process.

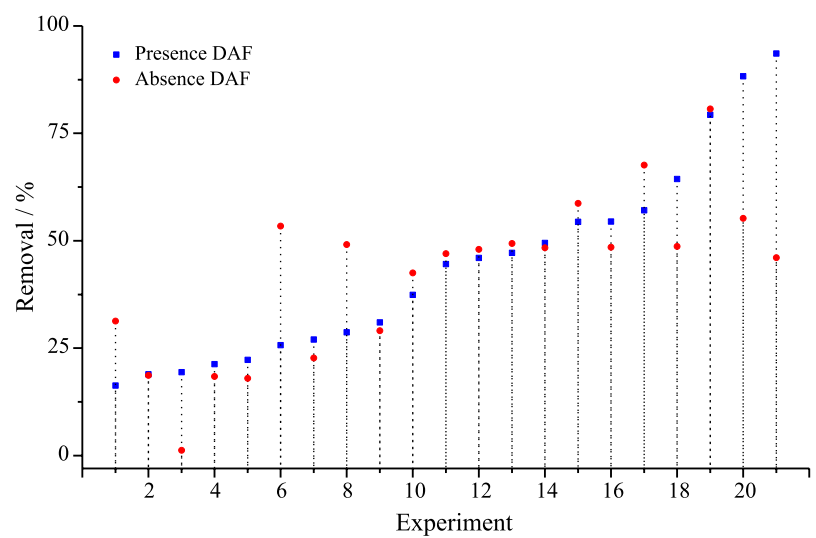

Figure 7. Electrocoagulation assays in presence and absence of dissolved air flotation (DAF).

PD and supporting electrolyte concentration are elevated, they cause an increase in effluent conductivity and an inhibition of electrodes' passivity. ${ }^{44,55,56}$ Thus, the formation of microbubbles was facilitated. Following this point, it is observed that it is possible to improve the removal by varying the ES and increasing the PD of the system (Figures $5 \mathrm{~d}$ and 6 ). The response surface (Figure $5 \mathrm{~h}$ ) is in accordance with the conditions of the desirability function 
(Figure 6). It is noted that for removals around 60 to $70 \%$, a time of more than $165 \mathrm{~min}$ is required in a $\mathrm{pH}_{\mathrm{i}}$ range from 3 to 4 . The quantity of flakes in the medium contributed to an efficient treatment. As follows, the increase of EP, $t$, and PD directly result in the production of flakes and consequently better the efficiency of electrocoagulation.

In an attempt to ratify the desirability function, experiments were carried out in triplicate conditions with an adjustment in the ES to $3 \mathrm{~cm}$. Even though the color did not showcase a mathematical adjustment, its study was carried out according to the relevance of this parameter in the treatment of industrial effluents. The results showed the values $163 \mathrm{uH}$ (color), $6.53\left(\mathrm{pH}_{\mathrm{f}}\right), 47 \mathrm{NTU}$ (turbidity), and $66 \%$ (removal). It is observed that, with the exception of color, these numbers are in accordance with the ranges estimated in Figure 6. To corroborate and elevate the importance of the results obtained, filtration was carried out. In this study, turbidity dropped to $1.58 \mathrm{NTU}$, and color reduced by $76 \%$ compared to initial conditions $(289 \mathrm{uH}$ at $\mathrm{pH} 4$ ). The persistent color after filtration is associated with the dye not removed. Since the toxicity of dyes is a relevant topic in the field of environmental impacts, their removal is essential for the maintenance of biota. In this way, it is justified to use this methodology in the removal of these contaminants at an industrial scale. However, if we want to make use of the tools presented here (desirability function), reducing additional costs and time, we should use additional strategies and tools that can remove the $34 \%$ of the remaining dye, thus placing the effluent in disposal conditions in water bodies.

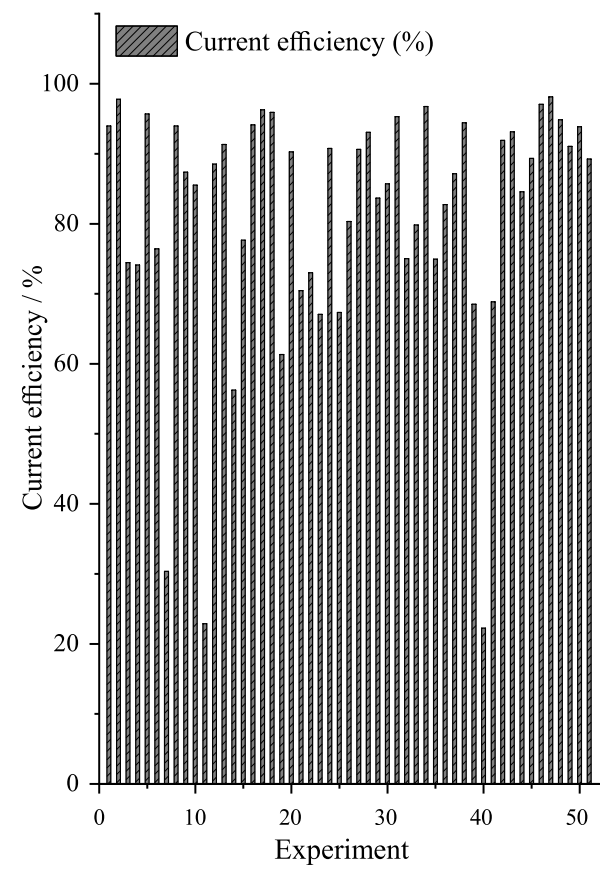

\section{Faradaic efficiency and energy consumption}

Figures $8 \mathrm{a}$ and $8 \mathrm{~b}$ show the current efficiency and energy consumption, respectively. Experiments 7 (30.4\%), $11(22.9 \%)$ and $40(22.2 \%)$ showed a convergence for low current efficiency. Significant variations in energy consumption occurred due to different electrolysis times (15-486 $\mathrm{min}$ ). Under optimized conditions, the current showed $94.1 \%$ efficiency with a consumption of $32.5 \mathrm{kWh} \mathrm{L}^{-1}$.

The PD is a function of the current that passes through the electrochemical cell, and it indicates that the increase in voltage can improve the removal of the dye, since the current determines the mass of electro-oxidized aluminum (coagulant), growth of flakes and microbubbles production. Efficient removals are associated with the amount of oxidized aluminum resulting in a greater production of flakes and consequently in the adsorption of pollutants. ${ }^{25,57,58}$

If the solution has a low electrical conductivity (low ion concentration), the electroneutrality of the effluent will be compromised and, consequently, the kinetics of the electrochemical process. These phenomena are driven by Ohm's law and cause polarization by ohmic drop. ${ }^{57}$ Thus, it is common to add electroactive species to increase conductivity, EC efficiency and reduce the ohmic resistance of the effluent. ${ }^{58}$ This procedure reduces energy consumption, the electrical voltage of the cell and, therefore, operating costs. ${ }^{14,57,58}$

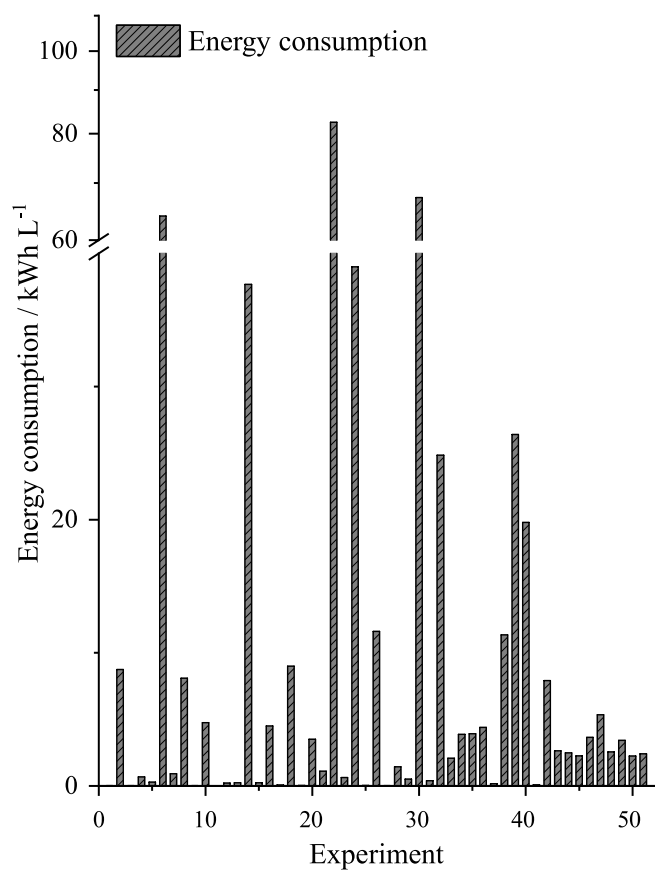

Figure 8. Current efficiency (a) and power consumption variation (b) for CCRD tests. 


\section{Conclusions}

This work dealt with the treatment of a synthetic textile wastewater by electrocoagulation/dissolved air flotation (EC-DAF) employing several statistical approaches (fractional factorial design (FFD) $2^{\mathrm{k}-\mathrm{p}}$; followed by a central composite rotational design (CCRD)). According to the obtained results, the following statements can be concluded: $(i)$ the number of electrodes, distance between them, reaction time, initial $\mathrm{pH}$, and potential difference significantly influence the process of removal of $\mathrm{MB}$, with only the pressure of the dissolved air being the variable that did not have a positive effect on the removal of the dye; (ii) the optimization of parameters showed that an electric current applied for $203 \mathrm{~min}$, on a sample with an initial $\mathrm{pH} 4.0$, and a voltage of $32 \mathrm{~V}$ showed a high dye removal $(95.1 \%)$ with significant reductions in color and turbidity, after simple filtration; (iii) the final $\mathrm{pH}$ and turbidity responses presented statistical adjustment, enabling the development of a predictive model; (iv) the final $\mathrm{pH}$ of the treated effluent was approximately 6.7 , in compliance with Brazilian legal requirements; $(v)$ even though the removal did not showcase any adjustment, it was achievable to create a predictive model for high removal levels (> 65\%).

In short, it was possible to achieve high dye removal efficiency and faradic efficiency (low operating cost) using a simple reactor with aluminum electrodes. Therefore, the proposed system has potential to be applied on a larger scale.

\section{Supplementary Information}

Supplementary data (ANOVA, regression coefficients, plot of experimental vs. predicted values, and normal probability plot), are available free of charge at http://jbcs.sbq.org.br as PDF file.

\section{Acknowledgments}

The authors gratefully acknowledge financial support from the Fundação de Amparo à Pesquisa e ao Desenvolvimento Científico e Tecnológico do Maranhão (FAPEMA).

\section{References}

1. Basaleh, A. A.; Al-Malack, M. H.; Saleh, T. A.; J. Environ. Chem. Eng. 2019, 7, 103107.

2. Shao, H.; Li, Y.; Zheng, L.; Chen, T.; Liu, J.; J. Taiwan Inst. Chem. Eng. 2017, 80, 525.
3. Sghaier, I.; Guembri, M.; Chouchane, H.; Mosbah, A.; Ouzari, H. I.; Jaouani, A.; Cherif, A.; Neifar, M.; J. Text. Eng. Fash. Technol. 2019, 5, 134.

4. Yaseen, D. A.; Scholz, M.; Int. J. Environ. Sci. Technol. 2019, 16, 1193.

5. Ubale, M. A.; Salkar, V. D.; Korean J. Chem. Eng. 2017, 34, 1044.

6. Energy Audit and Benchmarking Procedure in Textile Effluent Treatment Plants (ETPs); https://pantareiwater.com/downloads/ publications/energy-consumption/Energy\%20Consumption. pdf, accessed in June 2021.

7. Betancor-Abreu, A.; Mena, V. F.; González, S.; Delgado, S.; Souto, R. M.; Santana, J. J.; J. Water Process Eng. 2019, 31, 100865.

8. Lopez-Vizcaíno, R.; Sáez, C.; Cañizares, P.; Rodrigo, M. A.; Sep. Purif. Technol. 2012, 98, 88.

9. Sher, F.; Hanif, K.; Iqbal, S. Z.; Imran, M.; J. Water Process Eng. 2020, 33, 101101.

10. Mondal, S.; Purkait, M. K.; De, S.; Advances in Dye Removal Technologies, $11^{\text {th }}$ ed.; Springer: Singapore, 2018.

11. Ribeiro, T. S.; Grossi, C. D.; Merma, A. G.; dos Santos, B. F.; Torem, M. L.; Miner. Eng. 2019, 131, 8.

12. Prakash, R.; Majumder, S. K.; Singh, A.; Chem. Eng. Process. Process Intensif. 2018, 127, 249.

13. Mohtashami, R.; Shang, J. Q.; J. Cleaner Prod. 2019, 218, 335.

14. Adjeroud, N.; Elabbas, S.; Merzouk, B.; Hammoui, Y.; Felkai-Haddache, L.; Remini, H.; Leclerc, J. P.; Madani, K.; J. Electroanal. Chem. 2018, 811, 26.

15. Hacha, R. R.; Merma, A. G.; Couto, H. J. B.; Torem, M. L.; Powder Technol. 2019, 342, 308.

16. Dimoglo, A.; Sevim-Elibol, P.; Dinç, O.; Gökmen, K.; Erdoğan, H.; J. Water Process Eng. 2019, 31, 100877.

17. Devlin, T. R.; Kowalski, M. S.; Pagaduan, E.; Zhang, X.; Wei, V.; Oleszkiewicz, J. A.; J. Hazard. Mater. 2019, 862.

18. Qi, Z.; You, S.; Ren, N.; Electrochim. Acta 2017, 229, 96.

19. Changmai, M.; Pasawan, M.; Purkait, M. K.; Sep. Purif. Technol. 2019, 210, 463.

20. Massoudinejad, M.; Sh, N.; Sarkhosh, M.; Ahmadi, E.; Sm, M.; Yaghoobinejad, R.; J. Health 2017, 8, 121.

21. Haarhoff, J.; Edzwald, J. K.; Desalination 2013, 311, 90.

22. Wang, H.; Chen, X.-1.; Bai, Y.; Guo, C.; Zhang, L.; Waste Manage. 2012, 32, 1297.

23. Liu, N.; Wu, Y.; Ionics 2019, 25, 3953.

24. Deghles, A.; Kurt, U.; Chem. Eng. Process. Process Intensif. 2016, 104, 43.

25. Kobya, M.; Gengec, E.; Demirbas, E.; Chem. Eng. Process. Process Intensif. 2016, 101, 87.

26. Suárez-Escobar, A.; Pataquiva-Mateus, A.; López-Vasquez, A.; Catal. Today 2016, 266, 120.

27. Govindan, K.; Oren, Y.; Noel, M.; Sep. Purif. Technol. 2014, 133, 396. 
28. Hakizimana, J. N.; Gourich, B.; Chafi, M.; Stiriba, Y.; Vial, C.; Drogui, P.; Naja, J.; Desalination 2017, 404, 1.

29. Assémian, A. S.; Kouassi, K. E.; Zogbé, A. E.; Adouby, K.; Drogui, P.; J. Environ. Chem. Eng. 2018, 6, 5587.

30. Amani-Ghadim, A. R.; Aber, S.; Olad, A.; Ashassi-Sorkhabi, H.; Chem. Eng. Process. Process Intensif. 2013, 64, 68.

31. Mondal, B.; Srivastava, V. C.; Kushwaha, J. P.; Bhatnagar, R.; Singh, S.; Mall, I. D.; Sep. Purif. Technol. 2013, 109, 135.

32. Taheri, M.; Moghaddam, M. R. A.; Arami, M.; J. Environ. Manage. 2013, 128, 798.

33. American Public Health Association, American Water Works Association, Water Environment Federation; Standard Methods for the Examination of Water and Wastewater, $21^{\text {st }}$ ed.; American Public Health Association: Washington, 2005.

34. Statistica, v. 7.0; StatSoft Inc., Tulsa, OK, USA, 2004.

35. Rodrigues, M. I.; Iemma, A. F.; Experimental Design and Process Optimization, $1^{\text {st }}$ ed.; Press: New York, 2015.

36. Derringer, G.; Suich, R.; J. Qual. Technol. 1980, 12, 214.

37. Ghaedi, M.; Roosta, M.; Khodadoust, S.; Daneshfar, A.; J. Chromatogr. Sci. 2015, 53, 1222.

38. Costa Neto, J. J. G.; Amaral, P. F. F.; Leão, M. H. M. R.; Gomes, T. L. M.; Sant'Ana, G. C. F.; J. Food Stud. 2017, 6, 14.

39. Khaled, B.; Wided, B.; Béchir, H.; Elimame, E.; Mouna, L.; Zied, T.; Arabian J. Chem. 2019, 12, 1848.

40. Conselho Nacional do Meio Ambiente (CONAMA); Resolução No. 357, de 17 de Março de 2005, Dispõe sobre a Classificação dos Corpos de Água e Diretrizes Ambientais Para o Seu Enquadramento, Bem Como Estabelece as Condições e Padrões de Lançamento de Efluentes, e Dá Outras Providências; Diário Oficial da União (DOU): Brasília, No. 053, de 18/03/2005, p. 58-63.

41. Conselho Nacional do Meio Ambiente (CONAMA); Resolução No. 430, de 13 de Maio de 2011, Dispõe sobre as Condições e Padrões de Lançamento de Efluentes, Complementa e Altera a Resolução No. 357, de 17 de março de 2005, do Conselho Nacional do Meio Ambiente-CONAMA; Diário Oficial da União (DOU): Brasília, No. 92, de 16/05/2011, p. 89.
42. Holt, P. K.; Barton, G. W.; Wark, M.; Mitchell, C. A.; Colloids Surf., A 2002, 211, 233.

43. Panizza, M.; Barbucci, A.; Ricotti, R.; Cerisola, G.; Sep. Purif. Technol. 2007, 54, 382.

44. Chen, G.; Sep. Purif. Technol. 2004, 38, 11.

45. Lu, G.; Qu, J.; Tang, H.; Water Res. 1999, 33, 807.

46. Góes, M. C. C.; Albuquerque, C. C. V.; Cardoso, J. J. F.; Santana, S. A. A.; Silva, H. A. S.; Melo, S. M.; de Farias, R. F.; Bezerra, C. W. B.; Pharm. Chem. J. 2019, 6, 37.

47. Neris, A. M.; Chantelle, L.; Souza, J. J. N.; Ferreira, J. M.; Fonseca, M. G.; Santos, I. M. G.; Mater. Lett. 2019, 255, 126588.

48. Liu, H. J.; Qu, J. H.; Hu, C. Z.; Zhang, S. J.; Colloids Surf., A 2003, 216, 139.

49. Cañizares, P.; Martínez, F.; Lobato, J.; Rodrigo, M. A.; J. Hazard. Mater. 2007, 145, 233.

50. AlJaberi, F. Y.; Heliyon 2019, 5, e02307.

51. Leite, L. S.; Hoffmann, M. T.; Daniel, L. A.; J. Water Process Eng. 2019, 32, 100947.

52. Xue, J.; Zhong, H.; Wang, S.; J. Environ. Manage. 2019, 247, 1.

53. Azevedo, A.; Oliveira, H. A.; Rubio, J.; Miner. Eng. 2018, 127, 114.

54. Chaprão, M. J.; da Silva, R. C. F. S.; Rufino, R. D.; Luna, J. M.; Santos, V. A.; Sarubbo, L. A.; J. Biotechnol. 2018, 285, 15.

55. Moussa, D. T.; El-Naas, M. H.; Nasser, M.; Al-Marri, M. J.; J. Environ. Manage. 2017, 186, 24.

56. Mameri, N.; Yeddou, A. R.; Lounici, H.; Belhocine, D.; Grib, H.; Bariou, B.; Water Res. 1998, 32, 1604.

57. Ehsani, H.; Mehrdadi, N.; Asadollahfardi, G.; Bidhendi, G. N.; Azarian, G.; J. Environ. Chem. Eng. 2020, 8, 104263.

58. Ingelsson, M.; Yasri, N.; Roberts, E. P. L.; Water Res. 2020, $187,116433$.

Submitted: February 14, 2021

Published online: July 2, 2021 